\title{
JMSS-1: a new Martian soil simulant
}

Xiaojia Zeng ${ }^{1,2}$, Xiongyao Li ${ }^{1 *}$, Shijie Wang ${ }^{1}$, Shijie Li ${ }^{1}$, Nicole Spring ${ }^{3}$, Hong Tang ${ }^{1}$, Yang $\mathrm{Li}^{1}$ and Junming Feng ${ }^{1}$

\begin{abstract}
It is important to develop Martian soil simulants that can be used in Mars exploration programs and Mars research. A new Martian soil simulant, called Jining Martian Soil Simulant (JMSS-1), was developed at the Lunar and Planetary Science Research Center at the Institute of Geochemistry, Chinese Academy of Sciences. The raw materials of JMSS-1 are Jining basalt and Fe oxides (magnetite and hematite). JMSS-1 was produced by mechanically crushing Jining basalt with the addition of small amounts of magnetite and hematite. The properties of this simulant, including chemical composition, mineralogy, particle size, mechanical properties, reflectance spectra, dielectric properties, volatile content, and hygroscopicity, have been analyzed. On the basis of these test results, it was demonstrated that JMSS-1 is an ideal Martian soil simulant in terms of chemical composition, mineralogy, and physical properties. JMSS-1 would be an appropriate choice as a Martian soil simulant in scientific and engineering experiments in China's Mars exploration in the future.
\end{abstract}

Keywords: Martian soil simulant; JMSS-1; Mars analog; Mars exploration

\section{Background}

With the continuous development of the Chang'E lunar exploration program (Chang'E-1, Chang'E-2, and Chang'E-3), Mars exploration has become one of the key missions of China's deep space exploration program.

Martian soil, covering the entire surface of Mars, is an unconsolidated material which has a direct effect on the locomotion performance of the Mars Lander/Rover and the performance of other aerospace equipment (Bishop and Dummel 1996; Arvidson et al. 2004a, b). Reaching Mars and landing safely on it have proven to be challenging tasks, despite the success of recent missions (e.g., Curiosity). Therefore, in order to better prepare for orbiter and landing missions to Mars, it is essential to carry out a series of ground experiments using Martian soil before a robotic mission is launched to explore the surface of Mars (Marlow et al. 2008). However, no samples of Martian soil have been collected, even though Mars exploration activities have been carried out about 40 times within the last five decades.

In view of the lack of any Martian soil samples, a Martian soil simulant, as a substitute material for Martian soil, should be developed to replace real Martian soil to be used

\footnotetext{
* Correspondence: lixiongyao@vip.skleg.cn

'Lunar and Planetary Science Research Center, Institute of Geochemistry,

Chinese Academy of Sciences, Guiyang 55002, China

Full list of author information is available at the end of the article
}

for scientific and engineering experiments. Martian soil simulants are usually produced using terrestrial material (e.g., basalt, volcanic ash, and volcanic cinders). It has similar chemical composition, mineralogy, particle size, and physical properties to real Martian soil. Martian soil simulants are widely used in engineering and scientific experiments in terrestrial laboratories, which mainly include payload calibration, rover walking experiments, testing and verifying of aerospace equipment, and other simulation experiments related to Mars exploration (Gross et al. 2001; Anderson et al. 2009; Beegle et al. 2009; Moroz et al. 2009; Pirrotta 2010; ElShafie et al. 2012; Merrison et al. 2012; Yeomans et al. 2013).

Four types of Martian soil simulants (JSC Mars-1, MMS, Salten Skov I, and ES-X) have been developed in the USA and at the European Space Agency for different purposes, such as spectrometer calibration, testing of lander/rover instruments, and evaluating the physical effect of Martian soil on mechanical components. JSC Mars-1, produced by the Johnson Space Center (JSC), has been widely used throughout the scientific community (Mautner and Sinaj 2002; Buhler and Calle 2003; Ormond and Kral 2006; Sharma et al. 2008). MMS (Mojave Mars Simulant) is a basaltic Mars simulant that is available as whole rock, sand, and dust. MMS sand and MMS dust are produced by mechanically crushing Saddleback basaltic boulders. They have been used in

\section{实}

(c) 2015 Zeng et al.; licensee Springer. This is an Open Access article distributed under the terms of the Creative Commons Attribution License (http://creativecommons.org/licenses/by/4.0), which permits unrestricted use, distribution, and reproduction in any medium, provided the original work is properly credited. 
the development of the 2007/8 Phoenix Scout and Mars Science Laboratory mission (Peters et al. 2008). Salten Skov I is a Martian magnetic dust analog made from fine-grained magnetic iron oxide precipitate originating from Denmark. It is a good Martian dust analog in terms of grain size, magnetic properties, optical reflectance, and aggregation properties for application in wind tunnels and other dust suspension/deposition studies (Nørnberg et al. 2009). ES-X is an engineering soil produced by the European Space Agency. It has been used to test the locomotion performance of the ExoMars rover, which is planned for launch in 2018 (Brunskill et al. 2011; Gouache et al. 2011).

So far, only the USA and the European Space Agency have developed Martian soil simulants. The lack of a Martian soil simulant has limited the development of China's deep space exploration. To prepare for China's upcoming robotic mission to Mars, a new Martian soil simulant, called Jining Martian Soil Simulant (JMSS-1), has been developed. This paper describes its production process, properties, and how it compares with Martian soil and other simulants.

\section{Methods}

\section{Target simulant and raw material selection}

Martian soil is used to denote any loose, unconsolidated materials that can be distinguished from rocks, bedrock, or strongly cohesive sediments (Gellert et al. 2004). Physical weathering (e.g., impact events and wind abrasion) of a variety of intermediate to basic igneous rocks (basalts and probably basaltic andesites) is the presumed genesis of the majority of the soil, although minor chemical alterations to the source rocks and/or generated soil may occur (Wanke et al. 2001; Foley et al. 2003; Christensen et al. 2004a; Morris et al. 2004, 2006a, b; McSween et al. 2009). Data from ground-based landers/rovers and orbital spacecraft revealed that the Martian surface is dominated by basaltic soil composed primarily of pyroxene, plagioclase feldspar, and olivine, as well as minor amounts of Fe and $\mathrm{Ti}$ oxides (e.g., magnetite, ilmenite, and hematite) and alteration minerals (e.g., sulfates, phyllosilicates, and carbonates) (Yen et al. 2005; Morris et al. 2006a; Morris et al. 2006b; McSween et al. 2010; Bish et al. 2013). Martian surface soils measured by the Viking landers, Pathfinder, Spirit, Opportunity, and Curiosity show that the bulk chemical composition of these materials is relatively constant at widely spaced locations across the planet (Table 1).

In order to obtain a suitable Martian soil simulant that adequately represents Martian soil for engineering and scientific experiments in terrestrial laboratories, the target simulant should meet the following criteria: (1) chemical composition and mineralogy approximately similar to Martian soil; (2) particle size distribution within the range of Martian soil values (grain size $=1$ to $1000 \mu \mathrm{m}$, median size $=250$ to $300 \mu \mathrm{m}$ ); (3) bulk density and mechanical properties within the range of Martian soil values (bulk density $=1200$ to $1600 \mathrm{~g} / \mathrm{cm}^{3}$, cohesion $=0$ to $15 \mathrm{kPa}$, and internal friction angle $=20^{\circ}$ to $40^{\circ}$ ); and (4) other properties, such as magnetic properties and reflectance spectra, similar to those of Martian soil, but not precisely imitated.

Considering the specific requirements of a Martian soil simulant, the source rock for development of the simulant was selected following these two principles: (1) it has a similar chemical composition and mineralogy to Martian basaltic rock, which contains lower levels of $\mathrm{Al}_{2} \mathrm{O}_{3}$ and higher levels of total $\mathrm{Fe}$ compare to terrestrial basalt, and (2) it can be easily acquired in large quantities. As a result of research and surveys, basaltic lava rock from Jining in southern Inner Mongolia was selected. It is currently being mined as construction material and is available in large quantities for the development of a Martian soil simulant (Fig. 1). The source rock for the JMSS-1 Martian soil simulant is Miocene in age and located on the northern edge of the North China craton, west of the Hannuoba basaltic field (Zhang et al. 2005). The hand samples of this basalt are dark gray to black, massive, porphyritic with fine-grained phenocrysts, and cryptocrystalline. As shown in Fig. 2, Jining basalt primarily consists of plagioclase, pyroxene, olivine, and a minor amount of ilmenite. Table 2 shows the chemical composition of Jining basalt compared to Backstay rock discovered in the Columbia Hills by the Spirit Rover and Bounce rock discovered at the Meridiani Planum by the Opportunity Rover. These results show that Jining basalt is similar to Backstay rock and Bounce rock in geochemical composition, except it is higher in $\mathrm{Al}_{2} \mathrm{O}_{3}$ and lower in total $\mathrm{Fe}$ (Rieder et al. 2004; McSween et al. 2006). In contrast to terrestrial basalt, Martian soil generally has a high level of total Fe (16-20 wt\%). In order to produce a better simulant, magnetite and hematite, which are present in the Martian soil, were used as additives for the development of JMSS-1. The magnetite and hematite were collected from Hebei province in China.

\section{Production of JMSS-1}

JMSS-1 was produced by mechanically crushing Jining basalt with the addition of small amounts of magnetite and hematite collected from Hebei province in China. This mechanical crushing process more closely resembles the physical weathering/comminution processes of basaltic rocks on Mars, where meteoric impacts and wind abrasion are the mechanisms of comminution. The JMSS-1 Martian soil simulant was produced via the following steps: (1) coarse crushing: using a jaw crusher, the mined Jining basalt and hematite with diameters of approximately 100 to $300 \mathrm{~mm}$ were crushed into small rocks with diameters of $<3 \mathrm{~mm}$; (2) fine crushing: using 
Table 1 Major element composition of JMSS-1 in comparison with Martian soil and other Martian soil simulants (wt\%)

\begin{tabular}{|c|c|c|c|c|c|c|c|c|c|c|}
\hline & \multicolumn{7}{|c|}{ Martian soil } & \multicolumn{3}{|c|}{ Martian soil simulants } \\
\hline & Viking $1^{a}$ & Viking $2^{\mathrm{a}}$ & Pathfinder $^{\mathrm{b}}$ & Spirit $^{c}$ & Opportunity $^{d}$ & Curiosity $^{\mathrm{e}}$ & Average $^{f}$ & JSC Mars- $1^{g}$ & $\mathrm{MMS}^{9}$ & JMSS-1 \\
\hline $\mathrm{SiO}_{2}$ & 43.00 & 43.00 & 42.00 & 45.80 & 43.80 & 42.88 & 45.41 & 43.48 & 49.40 & $49.28 \pm 0.24$ \\
\hline $\mathrm{TiO}_{2}$ & 0.66 & 0.56 & 0.80 & 0.81 & 1.08 & 1.19 & 0.91 & 3.62 & 1.09 & $1.78 \pm 0.01$ \\
\hline $\mathrm{Al}_{2} \mathrm{O}_{3}$ & 7.30 & - & 10.30 & 10.00 & 8.55 & 9.43 & 9.71 & 22.09 & 17.10 & $13.64 \pm 0.33$ \\
\hline $\mathrm{Cr}_{2} \mathrm{O}_{3}$ & - & - & 0.30 & 0.35 & 0.46 & 0.49 & 0.36 & 0.03 & 0.05 & - \\
\hline $\mathrm{Fe}_{2} \mathrm{O}_{3}$ & 18.50 & 17.80 & 21.70 & & & & & 16.08 & 10.87 & $16.00 \pm 0.07$ \\
\hline $\mathrm{FeO}$ & & & & 15.80 & 22.33 & $19.19^{h}$ & 16.73 & & & \\
\hline $\mathrm{MnO}$ & - & - & 0.30 & 0.31 & 0.36 & 0.41 & 0.33 & 0.26 & 0.17 & $0.14 \pm 0.01$ \\
\hline $\mathrm{MgO}$ & 6.00 & - & 7.30 & 9.30 & 7.05 & 8.69 & 8.35 & 4.22 & 6.08 & $6.35 \pm 0.08$ \\
\hline $\mathrm{CaO}$ & 5.90 & 5.70 & 6.10 & 6.10 & 6.67 & 7.28 & 6.37 & 6.05 & 10.45 & $7.56 \pm 0.06$ \\
\hline $\mathrm{Na}_{2} \mathrm{O}$ & - & - & 2.80 & 3.30 & 1.60 & 2.72 & 2.73 & 2.34 & 3.28 & $2.92 \pm 0.09$ \\
\hline $\mathrm{K}_{2} \mathrm{O}$ & $<0.15$ & $<0.15$ & 0.60 & 0.41 & 0.44 & 0.49 & 0.44 & 0.70 & 0.48 & $1.02 \pm 0.03$ \\
\hline $\mathrm{P}_{2} \mathrm{O}_{5}$ & - & - & 0.70 & 0.84 & 0.83 & 0.94 & 0.83 & 0.78 & 0.17 & $0.30 \pm 0.01$ \\
\hline $\mathrm{SO}_{3}$ & 6.60 & 8.10 & 6.00 & 5.82 & 5.57 & 5.45 & 6.16 & 0.31 & 0.10 & - \\
\hline $\mathrm{Cl}$ & 0.70 & 0.50 & 0.90 & 0.53 & 0.44 & 0.69 & 0.68 & - & - & - \\
\hline LOI & - & - & - & - & - & - & & 17.36 & 3.39 & $0.48 \pm 0.17$ \\
\hline Total & 88.81 & 75.81 & 99.80 & 99.37 & 99.18 & 99.85 & 99.01 & 99.70 & 99.40 & 99.47 \\
\hline
\end{tabular}

"_" not analyzed

a Banin et al. (1992)

boley et al. (2003)

'Gellert et al. (2004)

d'Rieder et al. (2004)

eBlake et al. (2013)

${ }^{\mathrm{f}}$ Taylor and McLennan (2009)

${ }^{9}$ Peters et al. (2008)

${ }^{\mathrm{h}} \mathrm{Fe}_{2} \mathrm{O}_{3}+\mathrm{FeO}=19.19$. For the Viking Landers, Pathfinder soil, JSC Mars-1, MMS, and JMSS-1 total Fe is expressed as Fe $\mathrm{O}_{3}$. For Spirit and Opportunity, average soil total $\mathrm{Fe}$ is expressed as $\mathrm{FeO}$

a ball crusher, the coarse crushed Jining basalt, magnetite, and hematite were crushed to fine grains with diameters of $<1 \mathrm{~mm}$; (3) mixing: these fine-grained samples were systematically mixed (93 wt\% basalt, $5 \mathrm{wt} \%$ magnetite, and $2 \mathrm{wt} \%$ hematite); and (4) sieving and particle size adjustment: the grain size distribution was adjusted to achieve the target distribution by sieving the mixture.

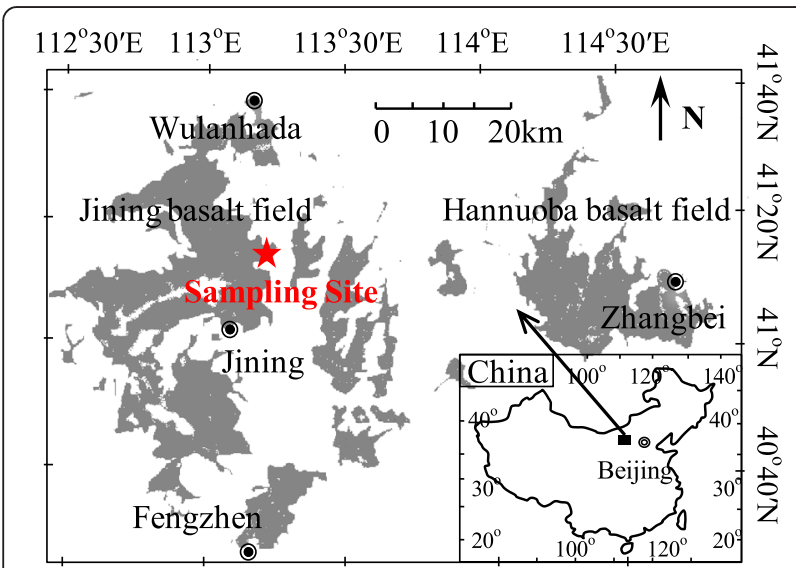

Fig. 1 Distribution of Jining basalt. The source basalt for JMSS-1 is located in Jining, southern Inner Mongolia

\section{Analytical methods}

Samples of Jining basalt and JMSS-1 were prepared and polished for scanning electron microscope analysis. Major mineral species in Jining basalt and JMSS-1 were observed and studied using a JEOL JSM-6460LV Scanning Electron Microscope operating at $15 \mathrm{kV}$ at the Institute of Geochemistry, Chinese Academy of Sciences. The major element compositions of Jining basalt and JMSS-1 were analyzed by X-ray fluorescence (XRF) following standard procedures at the State Key Laboratory of Ore Deposit Geochemistry at the Institute of Geochemistry, Chinese Academy of Sciences. Samples were ground to pass a 200mesh $(75-\mu \mathrm{m})$ sieve prior to analysis. The particle size distribution and specific gravity of JMSS-1 were measured by a laser particle size analyzer Mastersizer 2000 and Ultrapyc 1200e gas pycnometer (Quantachrome Instruments, USA), respectively, at the Lunar and Planetary Science Research Center, Institute of Geochemistry, Chinese Academy of Sciences. The mechanical properties of JMSS-1 were determined by conventional triaxial compression (CTC) experiments at the Institute of Rock and Soil Mechanics, Chinese Academy of Sciences. The reflectance spectrum of JMSS-1 was measured at the Technical Institute of Physics and Chemistry, Chinese Academy of Sciences. 


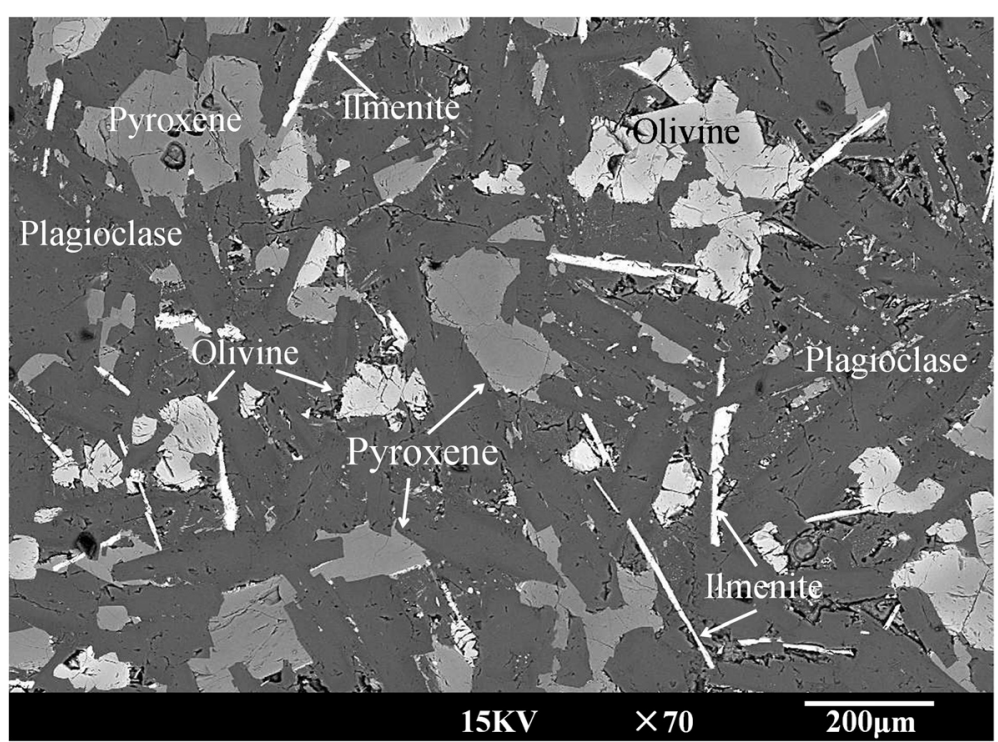

Fig. 2 Back-scattered electron image of Jining basalt. Jining basalt consists primarily of plagioclase, pyroxene, olivine, and a minor amount of ilmenite

The complex dielectric permittivity was determined by a resonant cavity perturbation method (accuracy $<3 \%$ ) at $9370 \mathrm{MHz}$ at the Lunar and Planetary Science Research Center, Institute of Geochemistry, Chinese Academy of Sciences (Zheng et al. 2005).

\section{Results}

\section{Chemical composition}

Table 1 provides the major element composition of JMSS-1 compared with MMS, JSC Mars-1, and descriptions of Martian soil from the Viking, Pathfinder, Spirit, Opportunity, and Curiosity landing sites. The test result for JMSS-1 is an average of three samples.

\section{Mineralogy}

From the X-ray diffraction (XRD) and scanning electron microscopy and energy dispersive spectrometry (SEMEDS) data, JMSS-1 is mainly composed of plagioclase, pyroxene, and olivine, as well as minor amounts of ilmenite, magnetite, and hematite (Fig. 3). The composition of individual mineral phases in JMSS-1 was also determined using SEM-EDS data. The result suggested that the plagioclase, olivine, and pyroxene in JMSS-1 tend to be calcic plagioclase ( An51-An60), forsteritic olivine ( Fo56-Fo70), and augite, respectively. Table 3 lists the SEM-EDS data for typical analysis points as seen in Fig. 3. It should also be noted that no altered minerals (e.g., sulfates, clays, or carbonates) were found in JMSS- 1 by XRD and SEM.

A hand magnet was used to gather the magnetic component from three samples of JMSS-1. The average magnetic component in JMSS-1 is about $5 \mathrm{wt} \%$, and the magnetic phase in JMSS-1 is magnetite, as indicated by the XRD and SEM-EDS data.

\section{Particle size and shape}

A back-scattered electron image of the typical particles of JMSS-1 is shown in Fig. 3. As shown in this image, most JMSS-1 particles are angular to subangular in shape. Figure 4 presents the particle size distribution curves of JMSS-1, JSC-1 Mars-1, and MMS sand (Allen et al. 1998; Peters et al. 2008). It indicates that the grain

Table 2 Chemical composition of Jining basalt compared to Backstay rock and Bounce rock (wt\%)

\begin{tabular}{llllllllllllll}
\hline & $\mathrm{SiO}_{2}$ & $\mathrm{TiO}_{2}$ & $\mathrm{Al}_{2} \mathrm{O}_{3}$ & $\mathrm{Cr}_{2} \mathrm{O}_{3}$ & $\mathrm{Fe}_{2} \mathrm{O}_{3}$ & $\mathrm{MnO}$ & $\mathrm{MgO}$ & $\mathrm{CaO}$ & $\mathrm{Na}_{2} \mathrm{O}$ & $\mathrm{K}_{2} \mathrm{O}$ & $\mathrm{P}_{2} \mathrm{O}_{5}$ & $\mathrm{LOI}$ & $\mathrm{Total}$ \\
\hline Jining basalt-1 & 51.07 & 1.71 & 14.50 & - & 11.07 & 0.12 & 7.03 & 8.18 & 3.14 & 1.11 & 0.31 & 1.86 & 100.10 \\
Jining basalt-2 & 51.08 & 1.69 & 14.51 & - & 10.93 & 0.13 & 6.89 & 8.05 & 3.14 & 1.09 & 0.30 & 2.20 & 100.01 \\
Backstay rock $^{\mathrm{a}}$ & 50.16 & 0.94 & 13.45 & 0.15 & $13.85^{\mathrm{c}}$ & 0.24 & 8.41 & 6.11 & 4.20 & 1.08 & 1.41 & - & 100.00 \\
Bounce rock $^{b}$ & 51.27 & 0.79 & 10.19 & 0.13 & $15.74^{c}$ & 0.43 & 6.46 & 12.62 & 1.31 & 0.10 & 0.96 & - & 100.00 \\
\hline
\end{tabular}

"-" not analyzed

${ }^{\mathrm{a}} \mathrm{McS}$ ween et al. (2006) and Nekvasil et al. (2009) ( $\mathrm{SO}_{3}$ and $\mathrm{Cl}$-free, normalized to $\left.100 \%\right)$

${ }^{\mathrm{b}}$ Rieder et al. (2004) ( $\mathrm{SO}_{3}$ and $\mathrm{Cl}$-free, normalized to $\left.100 \%\right)$

${ }^{\mathrm{c}}$ For Backstay rock and Bounce rock, total $\mathrm{Fe}$ is expressed as $\mathrm{FeO}$ 


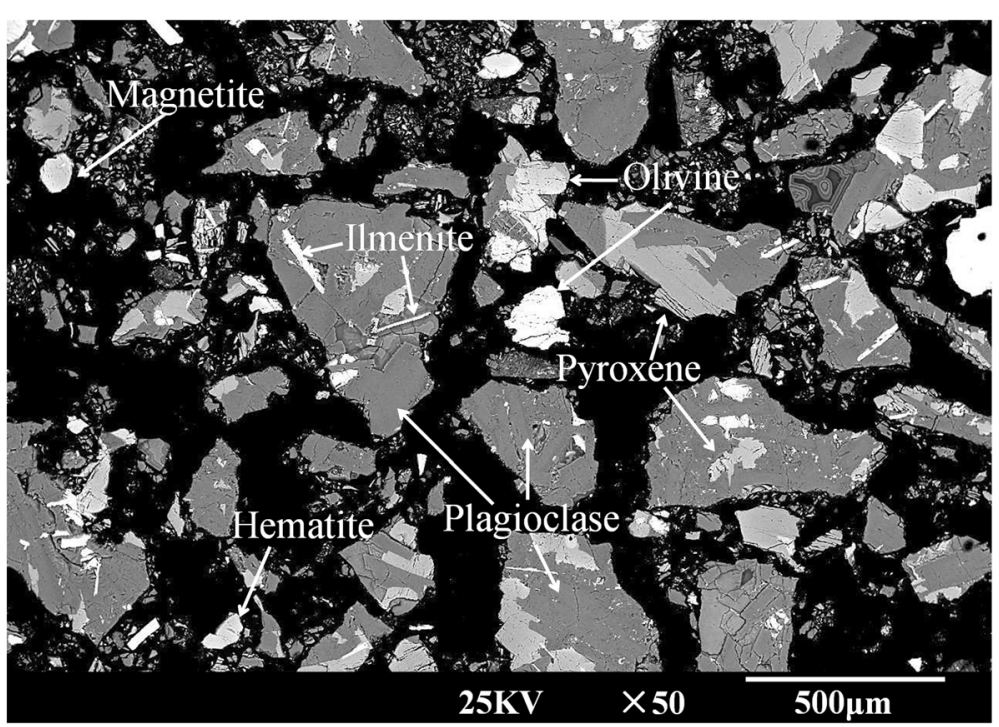

Fig. 3 Back-scattered electron image of JMSS-1. JMSS-1 consists primarily of plagioclase, pyroxene, and olivine, as well as minor amounts of ilmenite, magnetite, and hematite. Most JMSS-1 particles are angular to subangular in shape

size of JMSS- 1 is $<1 \mathrm{~mm}$, and the median and mean particle sizes of this sample are $\sim 300$ and $\sim 250 \mu \mathrm{m}$, respectively.

\section{Mechanical properties}

Table 4 presents the mechanical properties of JMSS-1 compared to MMS, JSC Mars-1, and Martian regolith observed at different Mars landing sites.

The specific gravity is the ratio of particle mass to the mass of an equal volume of water at $4{ }^{\circ} \mathrm{C}$. Measured for three JMSS-1 samples, the average specific gravity of JMSS1 particles is $2.88 \mathrm{~g} / \mathrm{cm}^{3}$. We measured the masses and volumes of several JMSS-1 samples to determine a mean bulk density of $1.45 \mathrm{~g} / \mathrm{cm}^{3}$. This value, compared to the particle density, infers a porosity of $49.65 \%$ for JMSS-1.

Table 3 Representative SEM-EDS data of major phases in JMSS-1 (wt\%)

\begin{tabular}{lllllll}
\hline & Olivine & Pyroxene & Plagioclase & Ilmenite & Magnetite & Hematite \\
\hline $\mathrm{SiO}_{2}$ & 37.69 & 52.95 & 52.25 & 2.43 & 1.38 & 0.78 \\
$\mathrm{TiO}_{2}$ & 0.19 & 0.75 & 0.15 & 47.05 & 0.25 & 0.39 \\
$\mathrm{Al}_{2} \mathrm{O}_{3}$ & 0.25 & 2.74 & 28.96 & 0.78 & 0.53 & 0.15 \\
$\mathrm{Cr}_{2} \mathrm{O}_{3}$ & 0.1 & 0.75 & 0.15 & 0.09 & 0.18 & 0.7 \\
$\mathrm{Fe}_{2} \mathrm{O}_{3}$ & 29.48 & 7.18 & 0.93 & 47.43 & 94.83 & 96.84 \\
$\mathrm{MnO}$ & 0.48 & 0.18 & 0.06 & 0.57 & 0.45 & 0.91 \\
$\mathrm{MgO}$ & 30.87 & 16.12 & 1.16 & 0.62 & 0.89 & 0 \\
$\mathrm{CaO}$ & 0.41 & 18.25 & 10.99 & 0.36 & 0.34 & 0.18 \\
$\mathrm{Na}_{2} \mathrm{O}$ & 0.39 & 0.6 & 4.06 & 0.27 & 0.35 & 0 \\
$\mathrm{~K}_{2} \mathrm{O}$ & 0.14 & 0.11 & 0.39 & 0.3 & 0.35 & 0.05 \\
$\mathrm{P}_{2} \mathrm{O}_{5}$ & 0 & 0.35 & 0.91 & 0.1 & 0.44 & 0 \\
\hline
\end{tabular}

The angle of internal friction of JMSS-1 is approximately $40.6^{\circ}$, and the cohesion of this material is approximately $0.33 \mathrm{kPa}$. Figure 5 shows the Mohr stress circles which were used to determine the angle of internal friction and cohesion for of JMSS-1.

\section{Reflectance spectra}

The visible to near-IR spectra of JMSS-1, MMS sand, and JSC Mars-1 are shown in Fig. 6 (Allen et al. 1998; Peters et al. 2008). The reflectance spectrum of JMSS-1 is similar to those of JSC Mars-1 and MMS sand. Each has a rise in reflectance value from 400 to $700 \mathrm{~nm}$, with an absorption band in the $900-$ to $1100-\mathrm{nm}$ region, and

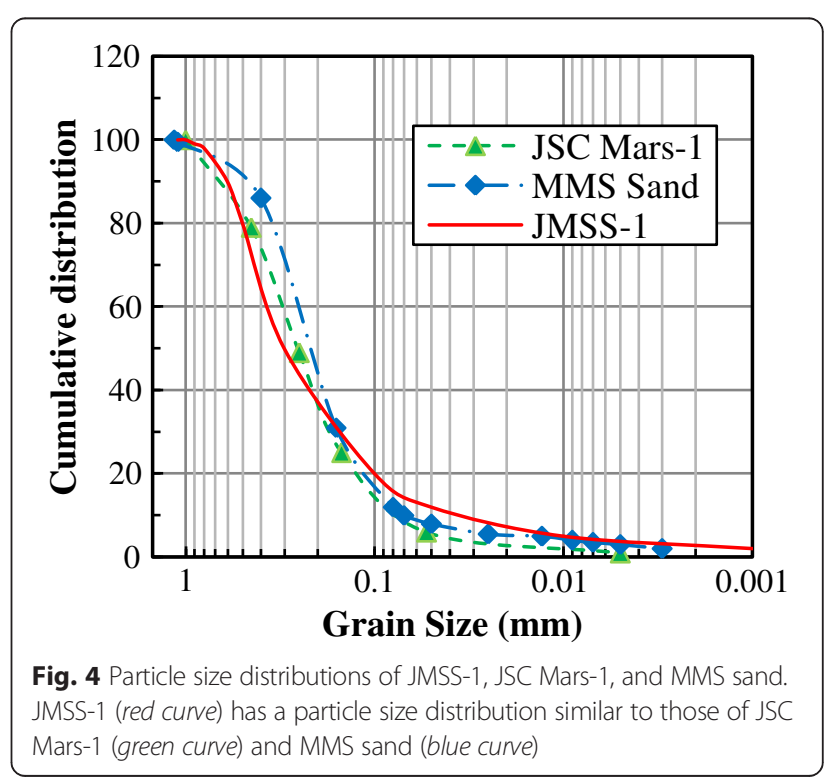


Table 4 Mechanical properties of JMSS-1, MMS, JSC Mars-1, and Martian regolith at different Mars landing sites

\begin{tabular}{|c|c|c|c|c|}
\hline & Soil type & $\begin{array}{l}\text { Bulk density } \\
\left(\mathrm{kg} / \mathrm{cm}^{3}\right)\end{array}$ & $\begin{array}{l}\text { Cohesion } \\
(\mathrm{kPa})\end{array}$ & $\begin{array}{l}\text { Internal friction angle } \\
\left({ }^{\circ}\right)\end{array}$ \\
\hline JMSS-1 & Soil simulant & 1450 & 0.33 & 40.6 \\
\hline MMS sand ${ }^{a}$ & Soil simulant & $1341-1384$ & $0.81-1.96$ & $38-39$ \\
\hline MMS dust ${ }^{\mathrm{a}}$ & Dust analog & $911-1078$ & $0.38-0.53$ & $30-31$ \\
\hline JSC Mars- $1^{\mathrm{b}}$ & Soil simulant & 835 & 1.91 & 47 \\
\hline Spirit Rover ${ }^{c}$ & Drift material & $1200-1500$ & $1-15$ & $\sim 20$ \\
\hline Opportunity Rover $^{d}$ & Surface soil & $\sim 1300$ & $1-5$ & $\sim 20$ \\
\hline Pathfinder ${ }^{\mathrm{e}}$ & Drift material & $1285-1518$ & $0-0.42$ & 34.3 \\
\hline Pathfinder ${ }^{\mathrm{e}}$ & Crusty material & $1422-1636$ & $0.17 \pm 0.18$ & $37.0 \pm 2.6$ \\
\hline Viking Lander $1^{f}$ & Drift material & $1150 \pm 150$ & $1.6 \pm 1.2$ & $18.0 \pm 2.4$ \\
\hline Viking Lander $1^{f}$ & Blocky material & $1600 \pm 400$ & $5.1 \pm 2.7$ & $30.8 \pm 2.4$ \\
\hline Viking Lander $2^{f}$ & Crusty material & $1400 \pm 200$ & $1.1 \pm 0.8$ & $34.5 \pm 4.7$ \\
\hline
\end{tabular}

apeters et al. (2008)

${ }^{\mathrm{b}}$ Allen et al. (1998)

${ }^{\mathrm{c}}$ Arvidson et al. (2004a)

${ }^{\mathrm{d}}$ Arvidson et al. (2004b)

eMoore et al. (1999)

f Moore and Jakosky (1989)

a generally flat reflectance from 1000 to $2400 \mathrm{~nm}$ as shown in Fig. 7. The existence of a band at $1900 \mathrm{~nm}$ in these simulant spectra is likely due to the presence of $\mathrm{OH}$ and $\mathrm{H}_{2} \mathrm{O}$.

\section{Dielectric properties}

Measurements of the dielectric properties of Martian soil simulant and other materials can help to anticipate radar performance on Mars, because radar signal penetration is influenced by the dielectric properties of the penetrated materials (Olhoeft and Capron 1993; Williams and Greeley 2004). The dielectric constant $\left(\varepsilon^{\prime}\right)$ and loss $(\tan \delta)$ of JMSS1 at $9370 \mathrm{MHz}$ are about 5.9 and 0.07 (accuracy $<3 \%$ ), respectively.

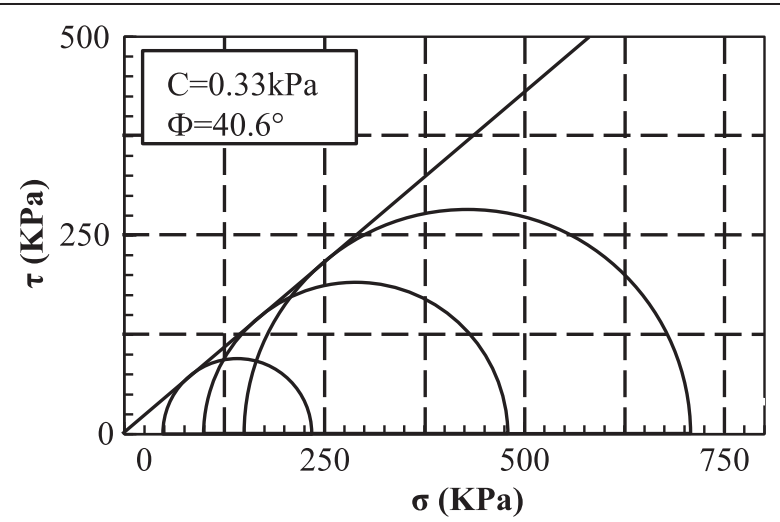

Fig. 5 CTC experiment of JMSS-1 Mohr stress circles. Mohr stress circles used to determine the angle of internal friction $\left(40.6^{\circ}\right)$ and cohesion (0.33 kPa) for JMSS-1
Volatile content and hygroscopicity

In order to determine the volatile content of JMSS-1, a 10-g JMSS-1 sample was prepared for a heating experiment in a high-temperature furnace. The weight losses of JMSS- 1 after $1 \mathrm{~h}$ range from $\sim 1.49 \mathrm{wt} \%$ at $100{ }^{\circ} \mathrm{C}$ to $\sim 4.7$ wt $\%$ at $500{ }^{\circ} \mathrm{C}$. These results represent total volatile loss, which is probably dominated by $\mathrm{H}_{2} \mathrm{O}$.

The hygroscopic property of the Martian soil simulant is an important parameter in experiments and tests, because its physical properties will probably change with the absorption of water. We prepared a 10-g JMSS-1 sample during a moderately humid day $\left(20{ }^{\circ} \mathrm{C}\right.$ and $50 \%$ relative humidity). This sample was then place in a tank at a temperature of $20{ }^{\circ} \mathrm{C}$ and a humidity of $80 \%$. Its

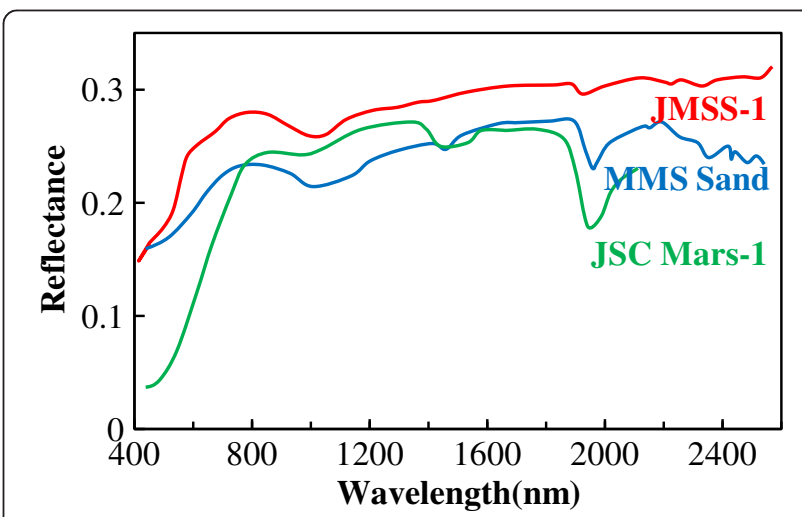

Fig. 6 Reflectance spectra of JMSS-1, JSC Mars-1, and MMS sand. Reflectance spectra of JMSS-1 (red curve) are similar to those of JSC Mars-1 (green curve) and MMS sand (blue curve) in the 400- to 2500-nm region 


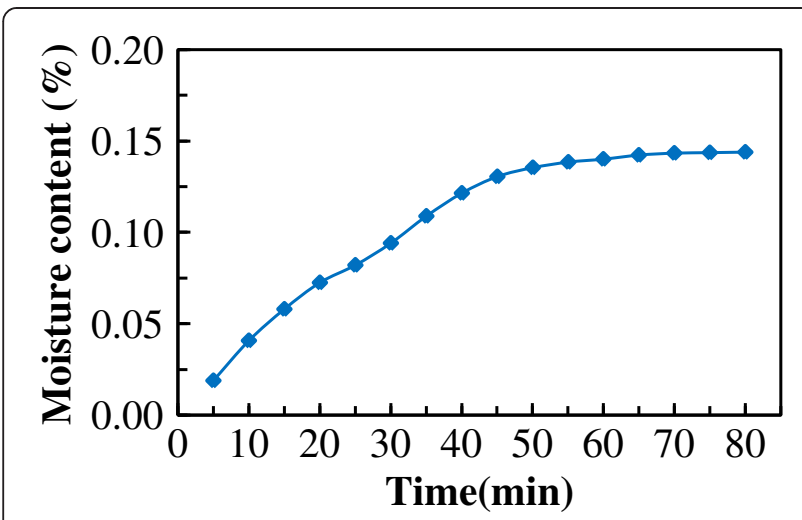

Fig. 7 Hygroscopic property of JMSS-1. JMSS-1 absorbs moisture relatively fast in the initial phase, and its moisture content reaches. approximately $0.14 \%$ after 70 min

moisture content was measured every 5 min until the moisture content became approximately constant. Figure 7 presents the variation of moisture content against time, which indicates the hygroscopic property. During a 5-min period, JMSS-1 gained approximately $0.018 \mathrm{wt} \%$. The moisture content then became approximately constant at $0.14 \mathrm{wt} \%$ after $70 \mathrm{~min}$.

\section{Discussion}

\section{Comparison with Martian soil}

Much of the Martian surface is covered by unconsolidated soils derived from a variety of impact, eolian, and thermal cycle stresses, as well as chemical alterations, including reaction of the sulfate and/or ferric phases and salts with water provided either by the diurnal moisture variations over long time periods or by other more speculative forms of water (Bishop et al. 2002; Blake et al. 2013). Despite the presence of secondary alteration minerals, the ubiquity of olivine and pyroxene in Martian soil suggests that physical weathering has dominated over chemical weathering during the time that Martian soil has been exposed on the surface (Christensen et al. 2004b; McGlynn et al. 2012). JMSS-1 has undergone a mechanical crushing process that more closely resembles the physical weathering processes on Mars, where meteoric impact and wind abrasion provide mechanisms for comminution. This means that JMSS-1 more closely resembles the physical weathering product of basaltic rocks of Mars.

As shown in Table 1, Martian soil measured at six different landing sites shows homogeneity amongst its main chemical components. However, there are also regional and trace components in Martian soil, such as carbonate, chlorohydrocarbon, and glassy spherules identified at the Gale Crater (Blake et al. 2013; Leshin et al. 2013; Minitti et al. 2013). In situ measurements of soil samples indicate that Martian soil contains approximately 43-45 wt\% $\mathrm{SiO}_{2}, 16-20 \mathrm{wt} \% \mathrm{FeO}, 7-10 \mathrm{wt} \%$
$\mathrm{Al}_{2} \mathrm{O}_{3}, 6-9$ wt $\% \mathrm{MgO}, 6-8$ wt $\% \mathrm{CaO}, 0.7-0.9$ wt $\% \mathrm{P}_{2} \mathrm{O}_{5}$, and 5-8 wt\% $\mathrm{SO}_{3}$ (Banin et al. 1992; Foley et al. 2003; Gellert et al. 2004; Rieder et al. 2004; Blake et al. 2013). As shown in Table 1, compared to Martian soil, JMSS-1 has higher levels of $\mathrm{SiO}_{2}(49.28 \mathrm{wt} \%)$ and $\mathrm{Al}_{2} \mathrm{O}_{3}$ (13.64 wt\%) and lower levels of $\mathrm{SO}_{3}$ and $\mathrm{P}_{2} \mathrm{O}_{5}(0.3 \mathrm{wt} \%)$.

Based on data from Mars rovers (Spirit, Opportunity, and Curiosity), Martian surface soil consists primarily of plagioclase, pyroxene, and olivine, with minor amounts of $\mathrm{Fe}$ and $\mathrm{Ti}$ oxides (e.g., magnetite, ilmenite, and hematite) and various alteration minerals (e.g., sulfates, phyllosilicates, and carbonate) (Yen et al. 2005; McSween et al. 2010; Bish et al. 2013). As for the composition of individual mineral phases in Martian soil at the Spirit, Opportunity, and Curiosity landing sites, plagioclase tends to be sodic to intermediate ( An57) in composition, olivine tends to be forsteritic olivine ( Fo62), and pyroxene tends to favor Ca-rich pyroxene (e.g., augite) with subordinate amounts of Ca-poor pyroxene (e.g., pigeonite) (Christensen et al. 2004a, b; Bish et al. 2013). These results are consistent with the mineralogy of JMSS-1, which is also dominated by plagioclase, pyroxene, and olivine, with minor amounts of magnetite, ilmenite, and hematite. In addition, the individual mineral phases in JMSS-1 tend to be calcic plagioclase ( An51-An60), forsteritic olivine $(\sim$ Fo56-Fo70), and augite, respectively. These results demonstrate that JMSS- 1 is a good mineralogical analog for the igneous mineral composition of Martian soil. It should be noted that JMSS-1 does not contain the alteration minerals that have been found in Martian soil. In order to simulate Martian soil more accurately, minor amounts of alteration minerals (e.g., sulfates, carbonates, and clays) need to be added to JMSS-1 in future work.

The Viking and Pathfinder missions estimated the magnetic materials in Martian soil to be 1-7 wt\% (Hargraves et al. 1977; Madsen et al. 1999; Bertelsen et al. 2004). Magnetite is thought to be the main magnetic phase in Martian regolith, and hematite is thought to be responsible for the red surface of Mars (Hargraves et al. 1977, 1979; Moore and Jakosky 1989; Hviid et al. 1997; Madsen et al. 1999, 2003). This is consistent with JMSS-1, which has an average magnetic component (magnetite) of $\sim 5$ and $\sim 2 \mathrm{wt} \%$ hematite.

Based on data from the Mars landers/rovers (Table 4), the bulk density and mechanical properties of JMSS-1 are within the range of Martian soil values. The grain size of JMSS-1 is also similar to Martian soil, with a particle size of approximately $10-500 \mu \mathrm{m}$ observed by Viking, Pathfinder, Spirit, and Opportunity (Moore and Jakosky 1989; Moore et al. 1999; Golombek et al. 2008).

\section{Comparison with other reported simulants}

By way of comparison, JMSS-1 has similar chemical composition, mineralogy, and physical properties to the 
Martian soil simulant currently in common use (JSC Mars1 and MMS).

JSC Mars-1 is an altered volcanic ash mainly composed of plagioclase, along with minor $\mathrm{Ti}$ magnetite, Ca-rich pyroxene, olivine, glassy, ferric oxide particles, and less than $1 \mathrm{wt} \%$ of crystalline clay minerals or phyllosilicates (Allen et al. 1998). The significant difference between JSC Mars- 1 and JMSS- 1 is that JMSS- 1 is largely crystalline and contains more pyroxene, olivine, and hematite, while JSC Mars- 1 is primarily glassy in texture and contains ferric oxide particles. In addition, JMSS- 1 has low levels of $\mathrm{TiO}_{2}$ and $\mathrm{Al}_{2} \mathrm{O}_{3}$ and higher levels of $\mathrm{SiO}_{2}$ and $\mathrm{MgO}$ compared to JSC Mars-1 (Table 1).

Compared to MMS, JMSS- 1 contains less $\mathrm{Al}_{2} \mathrm{O}_{3}$ and $\mathrm{CaO}$ and more $\mathrm{Fe}_{2} \mathrm{O}_{3}$ (Table 1). The mineral composition of JMSS-1 is in agreement with that of MMS, which mainly consists of plagioclase and pyroxene, along with minor olivine, ilmenite, and hematite (Peters et al. 2008).

As for the magnetic properties, JMSS-1 contains $\sim 5$ wt $\%$ magnetite, which is the main magnetic phase in Martian regolith, whereas JSC Mars-1 has $\sim 25 \mathrm{wt} \%$ Ti magnetite, and the weak magnetic mineral phases in MMS are most likely ilmenite and hematite (Moore and Jakosky 1989; Allen et al. 1998; Madsen et al. 1999; Bertelsen et al. 2004; Morris et al. 2006b; Peters et al. 2008).

The bulk density of JMSS-1 is significantly greater than those of JSC Mars-1 and MMS (Table 4), which is probably due to the addition of magnetite and hematite.

The volatile loss of JMSS- 1 was $\sim 1.49$ wt $\%$ at $100{ }^{\circ} \mathrm{C}$ and $\sim 4.7 \mathrm{wt} \%$ at $500{ }^{\circ} \mathrm{C}$. This result is consistent with MMS, which has a volatile loss of $1.7 \mathrm{wt} \%$ at $100{ }^{\circ} \mathrm{C}, 7.2$ wt $\%$ at $500{ }^{\circ} \mathrm{C}$, and lower than values for JSC Mars-1 (volatile loss ranging from $7.8 \mathrm{wt} \%$ at $100{ }^{\circ} \mathrm{C}$ to $21.1 \mathrm{wt} \%$ at $600{ }^{\circ} \mathrm{C}$ ) (Allen et al. 1998; Peters et al. 2008).

\section{Conclusions}

We identified a basaltic rock in China that is available as raw material for the development of a Martian soil simulant. A new Martian soil simulant, JMSS-1, was produced by mechanically crushing Jining basalt with the addition of small amounts of magnetite and hematite. This simulant has undergone a mechanical comminution process that closely resembles the physical weathering processes on Mars where meteoric impact and wind abrasion are the mechanisms for comminution. JMSS-1 has similar chemical composition, mineralogy, and physical properties to Martian basaltic soil and can be used for the testing of Mars landers/rovers, the development of future instruments, and other scientific and engineering experiments in China's Mars exploration program.

\section{Abbreviation}

JMSS-1: Jining Martian Soil Simulant.

\section{Competing interests}

The authors declare that they have no competing interests.

\section{Authors' contributions}

XZ prepared the samples, carried out the property measurements, and drafted the manuscript. $X L$ and SW conceived the study. NS helped to edit the manuscript. SL, $Y L, H T$, and JF participated in the design of the experiment. All authors read and approved the final manuscript.

\section{Acknowledgements}

We wish to thank Prof. Ping Shen, Prof. Binguang Liu, Prof. Fei Yu, Prof. Yongcun Zheng, Prof. Cunru Liu, Prof. Liming Zhou, and Prof. Xiangrong Yang for their kind help. We would also like to thank the anonymous reviewers for their suggestions and comments. This research was supported by the National Natural Science Foundation of China (Grant Nos. 41373067, 41403057, 41403059, and 41490630) and the West Light Foundation of the Chinese Academy of Sciences (Manufacture of lunar dust simulant).

\section{Author details}

${ }^{1}$ Lunar and Planetary Science Research Center, Institute of Geochemistry, Chinese Academy of Sciences, Guiyang 55002, China. 'University of Chinese Academy of Sciences, Beijing 10049, China. ${ }^{3}$ School of Earth, Atmospheric and Environmental Sciences, University of Manchester, Manchester, UK.

Received: 14 November 2014 Accepted: 15 May 2015

Published online: 20 May 2015

\section{References}

Allen CC, Jager KM, Morris RV, Lindstrom DJ, Lindstrom MM, Lockwood JP (1998) JSC Mars-1: a Martian soil simulant. Space 98:469-476

Anderson RC, Beegle LW, Peters GH, Fleming GM, Jandura L, Kriechbaum K, Manatt K, Okon A, Pounders E, Sollitt L, Sunshine D (2009) Particle transport and distribution on the Mars Science Laboratory mission: effects of triboelectric charging. Icarus 204(2):545-557. doi:10.1016/j.icarus.2009.07.006

Arvidson RE, Anderson RC, Bartlett P, Bell JF, Blaney D, Christensen PR, Chu P, Crumpler L, Davis K, Ehlmann BL, Fergason R, Golombek MP, Gorevan S, Grant JA, Greeley R, Guinness EA, Haldemann AFC, Herkenhoff K, Johnson J, Landis G, Li R, Lindemann R, McSween H, Ming DW, Myrick T, Richter L, Seelos FP, Squyres SW, Sullivan RJ, Wang A, Wilson J (2004a) Localization and physical properties experiments conducted by Spirit at Gusev Crater. Science 305(5685):821-824. doi:10.1126/science.1099922

Arvidson RE, Anderson RC, Bartlett P, Bell JF, Christensen PR, Chu P, Davis K, Ehlmann BL, Golombek MP, Gorevan S, Guinness EA, Haldemann AFC, Herkenhoff KE, Landis G, Li R, Lindemann R, Ming DW, Myrick T, Parker T, Richter L, Seelos FP, Soderblom LA, Squyres SW, Sullivan RJ, Wilson J (2004b) Localization and physical property experiments conducted by opportunity at Meridiani Planum. Science 306(5702):1730-1733. doi:10.1126/science.1104211 Banin A, Clark B, Wänke H (1992) Surface chemistry and mineralogy. Mars 1:594-625

Beegle LW, Peters GH, Anderson RC, Bhartia R, Ball AG, Sollitt L (2009) Particle sieving and sorting under simulated Martian conditions. Icarus 204(2):687-696. doi:10.1016/j.icarus.2009.07.008

Bertelsen P, Goetz W, Madsen MB, Kinch KM, Hviid SF, Knudsen JM, Gunnlaugsson HP, Merrison J, Nornberg P, Squyres SW, Bell JF, Herkenhoff KE, Gorevan S, Yen AS, Myrick T, Klingelhofer G, Rieder R, Gellert R (2004) Magnetic properties experiments on the Mars exploration rover Spirit at Gusev Crater. Science 305(5685):827-829. doi:10.1126/science.1100112

Bish DL, Blake DF, Vaniman DT, Chipera SJ, Morris RV, Ming DW, Treiman AH, Sarrazin P, Morrison SM, Downs RT, Achilles CN, Yen AS, Bristow TF, Crisp JA, Morookian JM, Farmer JD, Rampe EB, Stolper EM, Spanovich N, Team MS (2013) X-ray diffraction results from Mars Science Laboratory: mineralogy of Rocknest at Gale Crater. Science 341:6153. doi:10.1126/Science.1238932

Bishop J, Dummel A (1996) The influence of fine-grained hematite powder on the spectral properties of Mars soil analogs; VIS-NIR bi-directional reflectance spectroscopy of mixtures. In: Lunar and Planetary Institute Science Conference Abstracts., p 119

Bishop JL, Murchie SL, Pieters CM, Zent AP (2002) A model for formation of dust, soil, and rock coatings on Mars: physical and chemical processes on the Martian surface. J Geophys Res: Planets (1991-2012) 107(E11):7, -1-7-17

Blake DF, Morris RV, Kocurek G, Morrison SM, Downs RT, Bish D, Ming DW, Edgett KS, Rubin D, Goetz W, Madsen MB, Sullivan R, Gellert R, Campbell I, Treiman AH, McLennan SM, Yen AS, Grotzinger J, Vaniman DT, Chipera SJ, Achilles CN, 
Rampe EB, Sumner D, Meslin PY, Maurice S, Forni O, Gasnault O, Fisk M, Schmidt M, Mahaffy P, Leshin LA, Glavin D, Steele A, Freissinet C, NavarroGonzalez R, Yingst RA, Kah LC, Bridges N, Lewis KW, Bristow TF, Farmer JD, Crisp JA, Stolper EM, Marais DJD, Sarrazin P, Team MS (2013) Curiosity at Gale Crater, Mars: characterization and analysis of the Rocknest Sand Shadow. Science 341:6153. doi:10.1126/Science.1239505

Brunskill C, Patel N, Gouache TP, Scott GP, Saaj CM, Matthews M, Cui L (2011) Characterisation of Martian soil simulants for the ExoMars rover testbed. J Terramechanics 48(6):419-438. doi:10.1016/j.jterra.2011.10.001

Buhler CR, Calle CI (2003) Chemical implications due to the low electrical breakdown in the Martian atmosphere. Proc of the Electrostatics Soc Am Laplainan Press, Morgan Hill, CA, pp 565-579

Christensen PR, Ruff SW, Fergason RL, Knudson AT, Anwar S, Arvidson RE, Bandfield JL, Blaney DL, Budney C, Calvin WM, Glotch TD, Golombek MP, Gorelick N, Graff TG, Hamilton VE, Hayes A, Johnson JR, McSween HY, Mehall GL, Mehall LK, Moersch JE, Morris RV, Rogers AD, Smith MD, Squyres SW, Wolff MJ, Wyatt MB (2004a) Initial results from the Mini-TES experiment in Gusev Crater from the Spirit Rover. Science 305(5685):837-842. doi:10.1126/science.1100564

Christensen PR, Wyatt MB, Glotch TD, Rogers AD, Anwar S, Arvidson RE, Bandfield JL, Blaney DL, Budney C, Calvin WM, Faracaro A, Fergason RL, Gorelick N, Graff TG, Hamilton VE, Hayes AG, Johnson JR, Knudson AT, McSween HY, Mehall GL, Mehall LK, Moersch JE, Morris RV, Smith MD, Squyres SW, Ruff SW, Wolff MJ (2004b) Mineralogy at Meridiani Planum from the Mini-TES experiment on the Opportunity Rover. Science 306(5702):1733-1739. doi:10.1126/science.1104909

ElShafie A, Chevrier VF, Dennis N (2012) Application of planetary analog mechanical properties to subsurface geological investigations. Planet Space Sci 73(1):224-232. doi:10.1016/.jpss.2012.09.001

Foley CN, Economou TE, Clayton RN, Dietrich W (2003) Calibration of the Mars Pathfinder alpha proton X-ray spectrometer. J Geophys Res Planets 108:E12 doi:10.1029/2002je002018

Gellert R, Rieder R, Anderson RC, Bruckner J, Clark BC, Dreibus G, Economou T, Klingelhofer G, Lugmair GW, Ming DW, Squyres SW, d'Uston C, Wanke H, Yen A, Zipfel J (2004) Chemistry of rocks and soils in Gusev Crater from the alpha particle X-ray spectrometer. Science 305(5685):829-832. doi:10.1126/ science.1099913

Golombek M, Haldemann A, Simpson R, Fergason R, Putzig N, Arvidson R, Bell J III, Mellon M (2008) Martian surface properties from joint analysis of orbital, Earth-based, and surface observations. The Martian Surface-Composition, Mineralogy, and Physical Properties 1:468

Gouache TP, Patel N, Brunskill C, Scott GP, Saaj CM, Matthews M, Cui L (2011) Soil simulant sourcing for the ExoMars rover testbed. Planet Space Sci 59(8):779-787. doi:10.1016/.pss.2011.03.006

Gross FB, Grek SB, Calle Cl, Lee RU (2001) JSC Mars-1 Martian Regolith simulant particle charging experiments in a low pressure environment. J Electrostat 53(4):257-266. doi:10.1016/50304-3886(01)00152-8

Hargraves R, Collinson D, Arvidson R, Spitzer C (1977) The Viking magnetic properties experiment: primary mission results. J Geophys Res 82(28):4547-4558

Hargraves RB, Collinson DW, Arvidson RE, Cates PM (1979) Viking magnetic-properties experiment—extended mission results. J Geophys Res 84:8379-8384. doi:10.1029/ Jb084ib14p08379

Hviid SF, Madsen MB, Gunnlaugsson HP, Goetz W, Knudsen JM, Hargraves RB, Smith P, Britt D, Dinesen AR, Mogensen CT, Olsen M, Pedersen CT, Vistisen L (1997) Magnetic properties experiments on the Mars Pathfinder lander: preliminary results. Science 278(5344):1768-1770. doi:10.1126/science.278.5344.1768

Leshin L, Mahaffy P, Webster C, Cabane M, Coll P, Conrad P, Archer P, Atreya S, Brunner A, Buch A (2013) Volatile, isotope, and organic analysis of Martian fines with the Mars Curiosity Rover. Science 341(6153):1238937

Madsen MB, Hviid SF, Gunnlaugsson HP, Knudsen JM, Goetz W, Pedersen CT, Dinesen AR, Mogensen CT, Olsen M, Hargraves RB (1999) The magnetic properties experiments on Mars Pathfinder. J Geophys Res Planets 104(E4):8761-8779. doi:10.1029/1998je900006

Madsen MB, Bertelsen P, Goetz W, Binau CS, Olsen M, Folkmann F, Gunnlaugsson HP, Kinch KM, Knudsen JM, Merrison J, Nornberg P, Squyres SW, Yen AS, Rademacher JD, Gorevan S, Myrick T, Bartlett P (2003) Magnetic properties experiments on the Mars Exploration Rover mission. J Geophys Res Planets 108:E12. do:10.1029/ 2002 f002029

Marlow JJ, Martins Z, Sephton MA (2008) Mars on Earth: soil analogues for future Mars missions. Astron Geophys 49(2):20-23

Mautner MN, Sinaj S (2002) Water-extractable and exchangeable phosphate in Martian and carbonaceous chondrite meteorites and in planetary soil analogs. Geochim Cosmochim Ac 66(17):3161-3174. doi:10.1016/S0016-7037(02)00910-9
McGlynn IO, Fedo CM, McSween HY (2012) Soil mineralogy at the Mars Exploration Rover landing sites: an assessment of the competing roles of physical sorting and chemical weathering. J Geophys Res Planets 117:E01006. doi:10.1029/2011JE003861

McSween HY, Ruff SW, Morris RV, Bell JF, Herkenhoff K, Gellert R, Stockstill KR, Tornabene LL, Squyres SW, Crisp JA, Christensen PR, Mccoy TJ, Mittlefehldt DW, Schmidt M (2006) Alkaline volcanic rocks from the Columbia Hills, Gusev Crater, Mars. J Geophys Res Planets 111:E9. doi:10.1029/2006je002698

McSween HY, Taylor GJ, Wyatt MB (2009) Elemental composition of the Martian crust. Science 324(5928):736-739. doi:10.1126/science.1165871

McSween HY, McGlynn IO, Rogers AD (2010) Determining the modal mineralogy of Martian soils. J Geophys Res: Planets 115. doi: 10.1029/2010je003582

Merrison JP, Gunnlaugsson HP, Hogg MR, Jensen M, Lykke JM, Madsen MB, Nielsen MB, Nornberg P, Ottosen TA, Pedersen RT, Pedersen S, Sorensen AV (2012) Factors affecting the electrification of wind-driven dust studied with laboratory simulations. Planet Space Sci 60(1):328-335. doi:10.1016/j.pss.2011.10.008

Minitti M, Kah L, Yingst R, Edgett K, Anderson R, Beegle L, Carsten J, Deen R, Goetz W, Hardgrove C (2013) MAHLI at the Rocknest sand shadow: science and science-enabling activities. J Geophys Res Planets 118(11):2338-2360

Moore HJ, Jakosky BM (1989) Viking landing sites, remote-sensing observations, and physical properties of Martian surface materials. Icarus 81(1):164-184

Moore HJ, Bickler DB, Crisp JA, Eisen HJ, Gensler JA, Haldemann AFC, Matijevic JR, Reid LK, Pavlics F (1999) Soil-like deposits observed by Sojourner, the Pathfinder Rover. J Geophys Res Planets 104(E4):8729-8746. doi:10.1029/1998je900005

Moroz LV, Basilevsky AT, Hiroi T, Rout SS, Baither D, van der Bogert CH, Yakovlev Ol, Fisenko AV, Semjonova LF, Rusakov VS, Khramov DA, Zinovieva NG, Arnold G, Pieters CM (2009) Spectral properties of simulated impact glasses produced from Martian soil analogue JSC Mars-1. Icarus 202(1):336-353. doi:10.1016/.icarus.2009.02.007

Morris RV, Klingelhofer G, Bernhardt B, Schroder C, Rodionov DS, de Souza PA, Yen A, Gellert R, Evlanov EN, Foh J, Kankeleit E, Gutlich P, Ming DW, Renz F, Wdowiak T, Squyres SW, Arvidson RE (2004) Mineralogy at Gusev Crater from the Mossbauer spectrometer on the Spirit Rover. Science 305(5685):833-836 doi:10.1126/science.1100020

Morris RV, Klingelhofer G, Schroder C, Rodionov DS, Yen A, Ming DW, de Souza PA, Fleischer I, Wdowiak T, Gellert R, Bernhardt B, Evlanov EN, Zubkov B, Foh J, Bonnes U, Kankeleit E, Gutlich P, Renz F, Squyres SW, Arvidson RE (2006a) Mossbauer mineralogy of rock, soil, and dust at Gusev Crater, Mars: Spirit's journey through weakly altered olivine basalt on the plains and pervasively altered basalt in the Columbia Hills. J Geophys Res Planets 111:E2. doi:10.1029/2005je002584

Morris RV, Klingelhofer G, Schroder C, Rodionov DS, Yen A, Ming DW, de Souza PA, Wdowiak T, Fleischer I, Gellert R, Bernhardt B, Bonnes U, Cohen BA, Evlanov EN, Foh J, Gutlich P, Kankeleit E, McCoy T, Mittlefehldt DW, Renz F, Schmidt ME, Zubkov B, Squyres SW, Arvidson RE (2006b) Mossbauer mineralogy of rock, soil, and dust at Meridiani Planum, Mars: Opportunity's journey across sulfate-rich outcrop, basaltic sand and dust, and hematite lag deposits. J Geophys Res Planets 111:E12. doi:10.1029/2006je002791

Nekvasil H, McCubbin FM, Harrington A, Elardo S, Lindsley DH (2009) Linking the Chassigny meteorite and the Martian surface rock Backstay: insights into igneous crustal differentiation processes on Mars. Meteorit Planet Sci 44(6):853-869

Nørnberg P, Gunnlaugsson HP, Merrison JP, Vendelboe AL (2009) Salten Skov I: a Martian magnetic dust analogue. Planet Space Sci 57(5-6):628-631. doi:10.1016/.jpss.2008.08.017

Olhoeft G, Capron DE (1993) Laboratory measurements of the radiofrequency electrical and magnetic properties of soils from near Yuma. US Department of the Interior, US Geological Survey, Arizona

Ormond DR, Kral TA (2006) Washing methanogenic cells with the liquid fraction from a Mars soil simulant and water mixture. J Microbiol Meth 67(3):603-605. doi:10.1016/j.mimet.2006.05.007

Peters GH, Abbey W, Bearman GH, Mungas GS, Smith JA, Anderson RC, Douglas S, Beegle LW (2008) Mojave Mars simulant-characterization of a new geologic Mars analog. Icarus 197(2):470-479. doi:10.1016/j.icarus.2008.05.004

Pirrotta S (2010) Preliminary study on a novel coring system for planetary surface sampling. In: Proceedings of the 7th International Planetary Probe Workshop, Barcelona (Spain)., pp 14-18

Rieder R, Gellert R, Anderson RC, Bruckner J, Clark BC, Dreibus G, Economou T, Klingelhoffer G, Lugmair GW, Ming DW, Squyres SW, d'Uston C, Wanke H, Yen A, Zipfel I (2004) Chemistry of rocks and soils at Meridiani Planum from the alpha particle X-ray spectrometer. Science 306(5702):1746-1749. doi:10.1126/science.1104358 
Sharma R, Clark DW, Srirama PK, Mazumder MK (2008) Tribocharging characteristics of the Mars dust simulant (JSC Mars-1). IEEET Ind Appl 44(1):32-39. doi:10.1109/ Tia.2007.912761

Taylor SR, McLennan S (2009) Planetary crusts: their composition, origin and evolution, vol 10. Cambridge University Press

Wanke H, Bruckner J, Dreibus G, Rieder R, Ryabchikov I (2001) Chemical composition of rocks and soils at the Pathfinder site. Space Sci Rev 96(1-4):317-330. doi:10.1023/A:1011961725645

Williams KK, Greeley R (2004) Measurements of dielectric loss factors due to a Martian dust analog. J Geophys Res Planets 109:E10. doi:10.1029/2002je001957

Yen AS, Gellert R, Schroder C, Morris RV, Bell JF, Knudson AT, Clark BC, Ming DW, Crisp JA, Arvidson RE, Blaney D, Bruckner J, Christensen PR, DesMarais DJ, de Souza PA, Economou TE, Ghosh A, Hahn BC, Herkenhoff KE, Haskin LA, Hurowitz JA, Joliff BL, Johnson JR, Klingelhofer G, Madsen MB, McLennan SM, McSween HY, Richter L, Rieder R, Rodionov D, Soderblom L, Squyres SW, Tosca NJ, Wang A, Wyatt M, Zipfel J (2005) An integrated view of the chemistry and mineralogy of Martian soils. Nature 436(7047):49-54. doi:10.1038/Nature03637

Yeomans B, Saaj CM, Van Winnendael M (2013) Walking planetary rovers-experimental analysis and modelling of leg thrust in loose granular soils. J Terramechanics 50(2):107-120. doi:10.1016/j.jterra.2013.01.006

Zhang W, Han B, Du W, Liu Z (2005) Characteristics of mantle source for Jining Cenozoic basalts from southern Inner Mongolia: evidence from element and Sr-Nd-Pb isotopic geochemistry. Acta Petrologica Sinica 21(6):1569-1582

Zheng YC, Wang SJ, Ouyang ZY, Li XY (2005) Measurement of the dielectric properties of volcanic scoria and basalt at $9370 \mathrm{MHz}$. Acta Geol Sin Engl 79(2):291-295

\section{Submit your manuscript to a SpringerOpen ${ }^{\circ}$ journal and benefit from:}

- Convenient online submission

- Rigorous peer review

- Immediate publication on acceptance

- Open access: articles freely available online

- High visibility within the field

- Retaining the copyright to your article 